\title{
PEMANFAATAN DAUN GAHARU SEBAGAI PENGOBATAN SECARA ALAMI PENYAKIT KANKER DAN HIPERTENSI
}

Ursula Nova Yanti, Agustina Sumping, Melsi Dandri, Andi Dona, Timotius Tobias Secong, Sirilus Sirhi, Beni Setiawan

PGSD, STKIP Persada Khatulistiwa (Penulis 1, 2, 3 dan 6)

Pendidikan Biologi, STKIP Persada Khatulistiwa (Penulis 4)

PBSI, STKIP Persada Khatulistiwa (Penulis 5)

Pendidikan Matematika, STKIP Persada Khatulistiwa (Penulis 7)

Email: ursulanva123@gmail.com, agustinasumpin81@gmail.com, donaandi@gmail.com, melsidandri11@gmail.com, secongpsht@gmail.com, sirilussirhi@gmail.com,

benisetiawan1892@gmail.com

\begin{abstract}
Gaharu is a plant that has the Latin name Aquilaria Malaccensis. Gaharu tree has a local name, namely garu. Gharu plants have been empirically used by the Dayak people in Lanjak, Batang Lupar, Kapuas Hulu Regency as a medicinal plant. Gaharu leaves are processed into tea extracts which can be used for natural treatment of cancer and hypertension. This tea extract making training activity was carried out in Sungai Ukoi Village, Sungai Tebelian District, Sintang District. The method of implementation is by holding online training through virtual videocall whatsapp groups. Judging from the responses of the training participants, it shows that the partners are enthusiastic about participating in the training. After the training, the participants were asked to make a drying chamber used to make dried agarwood leaf tea. At the end of the activity the participants were asked to fill out a response questionnaire, the following data were obtained: 1) $95.45 \%$ for the assessment of the cleanliness of product appearance; 2) 93.50\% for attractiveness in product appearance; 3) 94.15\% for suitability of product portions; 4) $97.35 \%$ for product temperature suitability; 5) $93.22 \%$ for the attractive aroma of the product; 6) $92.14 \%$ for suitability of product taste.
\end{abstract}

Keywords: Tea, Agarwood Leaves, Natural Medicine, Cancer and Hypertension

\begin{abstract}
Abstrak: Gaharu adalah tanaman yang memiliki nama latin Aquilaria Malaccensis. Pohon gaharu memiliki nama lokal yaitu garu. Tanaman gharu telah secara empiris digunakan oleh masyarakat Dayak di Lanjak, Batang Lupar Kabupaten Kapuas Hulu sebagai tanaman obat. Daun gaharu ini diolah menjadi ekstrak teh yang dapat dimanfaatkan untuk pengobatan secara alami penyakit kanker dan hipertensi. Kegiatan pelatihan pembuatan ekstrak teh ini dilakukan di Desa Sungai Ukoi, Kecamatan Sungai Tebelian, Kabupaten Sintang. Metode pelaksanaan dengan mengadakan pelatihan secara daring melalui virtual videocall whatsapp grup. Dilihat dari respon peserta pelatihan menunjukan bahwa mitra antusias mengikuti pelatihan tersebut. Setelah pelatihan peserta diminta membuat tempat pengeringan yang digunakan untuk membuat teh daun gaharu kering. Pada akhir kegiatan peserta diminta untuk mengisi angket respon, diperoleh data sebagai berikut: 1) $95.45 \%$ untuk penilaian kebersihan penampilan produk; 2) $93.50 \%$ untuk kemenarikan dalam penampilan produk; 3) 94.15\% untuk kesesuaian porsi produk;
\end{abstract}


4) $97.35 \%$ untuk kesesuaian temperatur produk; 5) $93.22 \%$ untuk kemenarikan aroma produk; 6) $92.14 \%$ untuk kesesuaian rasa produk.

Kata Kunci: Teh, Daun Gaharu, Obat Alami, Kanker dan Hipertensi 


\section{PENDAHULUAN}

Kabupaten Sintang merupskan daerah yang terletak di bagian Timur Provinsi Kalimantan Barat. Daerah ini dilewati oleh garis Khatulistiwa dan terletak di antara $1^{\circ} 05^{\prime}$ Lintang Utara dan 0o46' Lintang Selatan serta 110o50' Bujur Timur dan 11320' Bujur Timur, dengan memiliki luas $21.635 \mathrm{~km}^{2}$ (Sirhi, dkk: 2018). Pada Kabupaten ini terdapat desa-desa yang memiliki keberagaman suku dan budaya serta memiliki potensi untuk penanaman tanaman obat. Salah satunya yaitu Desa Sungai Ukoi yang terletak di Kecamatan Sungai Tebelian. Penduduk Desa Sungai Ukoi merupakan salah satu bagian dari 24 Desa yang berada di Ibu Kota Kecamatan Sungai Tebelian, Kecamatan Sungai Tebelian Kabupaten Sintang. Desa ini memiliki Hutan Adat yang luas. Kenyataannya dibalik potensi yang ada, tetapi perekonomian Desa Sungai Ukoi masih sangat rentan terhadap fluktuasi gejolak perekonomian. Masyarakat Desa Sungai Ukoi Masih perlu Pendampingan dalam memberdayakan sumber daya Alam (SDA) yang ada, untuk meningkatkan perekonomian masyarakat (Sirhi, dkk: 2018). Desa ini merupakan tepat pelaksanaan kegiatan Pengabdian Kepada Masyarakat Tim PKM M STKIP Persada Khatulistiwa.

Tanaman Gaharu adalah tanaman yang memiliki nama latin aquilaria malaccensis. Pohon gaharu memiliki nama lokal yaitu garu. Tanaman ini sudah secara Tradisional digunakan oleh masyarakat Dayak sebagai tanaman obat-obatan. Tanaman ini mempunyai ciri-ciri seperti batang yang tidak berbanir, lurus, dan bersipat kayu keras. Kulit berwarna coklat keputihan dengan bertekstur halus. Tajut membulat, lebar dengan percabangan yang horizontal. Ciri-ciri kayu gaharu yang memiliki kualitas tinggi adalah bagian gubalnya memiliki warna hitam pekat yang merata, dan beraroma wangi ketika di potong. Sedangkan kayu gaharu yang memiliki kualiatas rendah memiliki ciriciri pada bagian gubal kayunya cenderung memiliki warna kecoklatan dan aroma wangi yang di hasilkan tidak sekuat kayu pohon gaharu berkualiatas tinggi.

Daun gaharu sudah diketahui oleh sebagian masyarakat di Desa Lanjak Kabupaten Kapuas Hulu dan di Desa Sungai Ukoi sebagai tumbuhan yang memiliki fungsi untuk pengobatan. Menurut sebagian peneliti, daun gaharu telah digunakan untuk mengobati beberapa penyakit salah satunya adalah penyakit Hipertensi dan Kanker. Pada zaman sekarang berbagai macam penyakit disebabkan oleh beberapa hal, ada yang disebabkan bakteri, virus, makanan, lingkungan atau faktor keturunan dalam anggota keluarga dan pola hidup yang tidak sehat. Salah satu penyakit yang sering muncul di dunia bahkan di negara kita sendiri yaitu Indonesia adalah penyakit Kanker dan Hipertensi.Tentu kita telah mengetahui penyakit ini adalah salah satu penyakit berbahaya dan dapat menyebabkan kematian.

Kandungan kimia yang ada pada tanaman gaharu antara lain adalah: noroxo-agarofuran, agarospirol, 3,4dihidroxy dihydroagarufuran, $p$ methoxybenzylaceton, aquilochin, Jinkohol, jinkohol ermol, dan kusunol. Inti gaharu atau gubal gaharu atau 
aloeswood atau eaglewood atau agarwood yang merupakan inti gaharu, damar wangi atau resin. Inti gaharu ini merupakan substansiaromatic (resin aromatic/berbau harum) yang termasuk dalam golongan sesquiterpen dan memiliki struktur kimia yang spesifik dan sampai saat ini belum bisa disintesis di laboratorium.

\section{METODE PELAKSANAAN}

Pelaksanaan Program Kreativitas Mahasiswa ini melalui beberapa tahapan yang telah dilaksanakan, antara lain:

Tahap Persiapan Awal

Kegiatan Observasi dilakukan dengan melakukan survei pada lokasi yang akan dijadikan program pengabdian masyarakat yakni di Desa Sungai Ukoi, Kecamatan Sungai Tebelian Kabupaten Sintang.

\section{Kegiatan Sosialisasi}

Kegiatan sosialisasi dilakukan tim mahasiswa untuk mengenal program kreativitas mahasiswa Pengabdian Kepada Masyarakat untuk pemanfaatan Daun Gaharu Sebagai Pengobatan Secara Alami Penyakit Kanker dan Hipertensi di Desa Sungai Ukoi, Dusun Pandan, Kecamatan Sungai Tebelian. Kegiatan ini dilakukan untuk memperkenalkan program teknik pemanfaatan Daun Gaharu Sebagai Pengobatan Secara Alami Penyakit Kanker dan Hipertensi.

\section{Tahap Implementasi / Pelaksanaan}

Pelatihan dilaksanakan di desa Sungai Ukoi. Kemudian dilanjutkan tahapan monitoring mulai dilakukan pada minggu ke 3 setelah melakukan kegiatan pelaksanaan pertama dari program yang dibuat. Monitoring juga dilakukan selama Program PKM-M yang berjudul "Pemanfaatan Daun Gaharu Sebagai Pengobatan Secara Alami Penyakit Kanker Dan Hipertensi” ini dilakukan untuk mengetahui cara pengolahan dan pembuatan ekstrak daun gaharu yang berupa teh. Melalui program ini, diharapkan artikel dapat dipublikasikan kedalam jurnal ilmiah, buku dapat dicetak dan produk bisa dipasarkan. Dengan demikian, masyakat pada umumnya dapat mengetahui manfaat dari ekstrak daun gaharu yaitu dapat menjadi obat alami penyakit kanker dan hipertensi. Keberlanjutan program Program Kreativitas Mahasiswa di Bidang Masyarakat (PKM-M) ini juga mampu. empat minggu berturut- turut dibulan keempat setelah satu minggu pengemasan.

Evaluasi

Evaluasi dilakukan selama satu minggu sekali untuk memantau program yang sudah dilaksanakan, sekaligus untuk mengevaluasi hasil kerja masyarakat yang mampu mempraktikkan pelaksanaan kegiatan setelah mengetahui tingkat keberhasilan dari kegiatan yang sudah terlaksana.

\section{HASIL DAN PEMBAHASAN}

$\begin{array}{crrr}\begin{array}{c}\text { Kegiatan } \\ \text { PKendukung }\end{array} & \text { beberapa } & \text { ini dapat } \\ \text { aspek }\end{array}$ kehidupan, yakni aspek ekonomi dan aspek sosial. Untuk aspek Ekonomi, ketika masyarakat sudah mempraktekkan secara mandiri proses pengolahan ekstrak teh daun gaharu, masyarakat sasaran dapat memasarkan 
produk yang telah dihasilakan sebelumnya. Dengan hal ini maka akan menjadi suatu nilai tambah bagi kehidupan ekonomi masyarakat Desa Sungai Ukoi, kabupaten sintang kalimatan barat pun akan menjadi lebih baik dari sebelumnya.

Kemudian untuk aspek sosial, dengan berhasilnya PKM-M di Desa Sungai Ukoi ini, diharapkan masyarakat dapat berbagi dan menginspirasi masyarakat desa lainnya bahwa banyak sekali tanaman alam Kalimantan yang berguna dan bermanfaat khususnya untuk pengobatan tradisional.

Memanfaatkan daun gaharu sebagai obat secara alami/tradisional. Dari hasil pelatihan disimpulkan bahwa selama proses pelatihan para anggota mitra antusias mengikuti pelatihan. Hal ini dilihat dari respon para anggota mitra. Setelah pelatihan peserta diminta membuat tempat pengeringan untuk pengeringan teh daun gaharu. Peserta diminta untuk mengisi angket yaitu: 1) kebersihan penampilan produk, 2) kemenarikan dalam penampilan produk, 3) kesesuaian porsi produk, 4) kesesuaian temperatur produk, 5) kemenarikan aroma produk, 6) kesesuaian rasa produk. Serta mitra dan beberapa masyarakat desa Sungai Ukoi ditanya tentang the daun gaharu ini mereka merespon dengan memberikan tanggapan sebagai berikut: 1) $95.45 \%$ untuk penilaian kebersihan penampilan produk; 2) $93.50 \%$ untuk kemenarikan dalam penampilan produk; 3) $94.15 \%$ untuk kesesuaian porsi produk; 4) 97.35\% untuk kesesuaian temperatur produk; 5) $93.22 \%$ untuk kemenarikan aroma produk; 6) $92.14 \%$ untuk kesesuaian rasa produk. Hasil angket respon para anggota mitra di uraikan pada tabel berikut:

Tabel 1. Hasil Aspek Penilaian

\begin{tabular}{|c|l|c|}
\hline No & \multicolumn{1}{|c|}{ Aspek Penilaian } & Hasil \\
\hline 1 & $\begin{array}{l}\text { Kebersihan } \\
\text { penampilan produk }\end{array}$ & $95.45 \%$ \\
\hline 2 & $\begin{array}{l}\text { Kemenarikan dalam } \\
\text { penampilan produk }\end{array}$ & $93.50 \%$ \\
\hline 3 & $\begin{array}{l}\text { Kesesuaian porsi } \\
\text { produk }\end{array}$ & $94.45 \%$ \\
\hline 4 & $\begin{array}{l}\text { Kesesuaian temperatur } \\
\text { produk }\end{array}$ & $97.35 \%$ \\
\hline 5 & $\begin{array}{l}\text { Kemenarikan aroma } \\
\text { produk }\end{array}$ & $93.22 \%$ \\
\hline 6 & $\begin{array}{l}\text { Kesesuaian rasa } \\
\text { produk }\end{array}$ & $92.14 \%$ \\
\hline
\end{tabular}

\section{SIMPULAN}

Pengabdian kepada masyarakat ini menyimpulkan bahwa tanaman gaharu dapat dimanfaatkan sebagai obat dan banyak masyarakat yang belum mengetahuinya. Dengan adanya kegiatan PKM-M ini mampu memberikan wawasan dan pengetahuan lebih luas untuk masyarakat mengenai cara pemanfaatan dan pengolahan daun gaharu sehingga dapat menjadi obat alami.

\section{DAFTAR RUJUKAN}

Mega, I. M., \& Swastini, D. A. (2010). Screening fitokimia dan aktivitas antiradikal bebas ekstrak metanol daun gaharu (Gyrinops versteegii). Jurnal Kimia (Journal of Chemistry).

Pratiwi, T. F. (2012). Kualitas hidup penderita kanker. Developmental and Clinical Psychology, 1(1). 
Sirhi, S., Astuti, S., \& Esti, F. R. (2018). IPTEK BAGI BUDIDAYA DAN EKSTRAK BAWANG DAYAK SEBAGAI OBAT ALTERNATIF. JAPI (Jurnal Akses Pengabdian Indonesia), 2(2), 1-7.

Zubaidi, A., \& Farida, N. (2017). Pertumbuhan bibit gaharu pada beberapa jenis naungan. CROP AGRO, Jurnal Ilmiah Budidaya, 1(2), 92-96. 